\title{
Design Methodology of a High-Frequency Transformers in Order to Increase Qualitative Indexes of Converters
}

\author{
Michal Frivaldsky ${ }^{1,2}$, Pavol Spanik ${ }^{1}$, Boris Kozacek ${ }^{2}$, Viliam Jaros ${ }^{2}$ and Andrej Kanovsky \\ ${ }^{1}$ Departmant of Mechatronics and Electronics, University of Zilina, Slovakia \\ ${ }^{2}$ Insitute of Electrical Engineering, University of Zilina, Slovakia, Michal.frivaldskyel.uniza.sk
}

\begin{abstract}
Energy efficiency and power density become main qualitative indexes of power electronic systems. This paper deals with derivation of the optimal design of high frequency transformer, which forms very important part of the dc-dc converter. Design procedure focuses on the possibilities of converter's power density and efficiency increase. In order to meet upcoming regulation and standards for dc-dc converter efficiency, the influence of transformer's core geometry is investigated. Precise simulation model of dc-dc converter, together with exact simulation model of transformer is used for evaluation. Finally, simulation results are provided in order to investigate the influence of core geometry on the efficiency of proposed converter.
\end{abstract}

Keywords-transformer design; LLC converter; efficiency; transformer core; high frequency

\section{INTRODUCTION}

Energy efficiency and power density become main qualitative indexes of power electronic systems. As a result of this, the requirements for compact power supply units (PSU) with high efficiency and power density are arising. Key factors for continual increase of both indicators have environmental, as well as economical character. Nowadays, in the field of industrial and consumer electronic the international standards and regulations are determined by international organizations like, U.S Energy Star, 80 Plus, Climate Savers, German Blue Angel, etc... (Fig I). Each year, more specifically from 2010 , the threshold is shifted by $3 \%$ to $4 \%$ or more. Accordingly, to Fig. I it can be said, that the coming trend designates threshold on $94 \%, 96 \%$, and $94 \%$ for $20 \%, 50 \%$ and $100 \%$ of load.

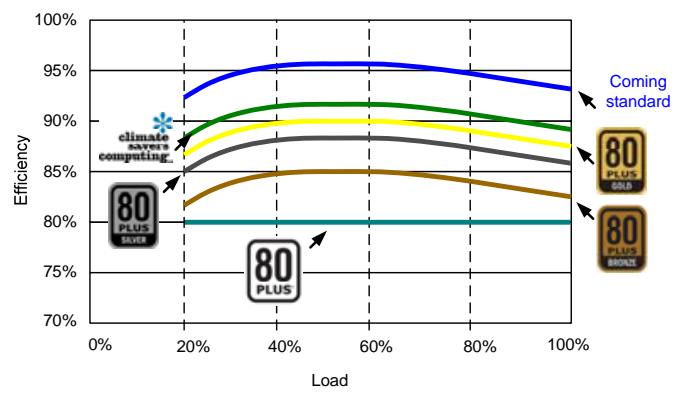

FIGURE I. INTERNATIONAL STANDARDS AND REQUREMENTS ON THE EFFECIENCY OF PSU.
Second requirement that is valid for proposed converters is constantly raising value of power density. Figure II illustrates process of the power density rise, based on which it is possible to see continuous and rapid rise [1]-[3]. Higher value of power density can be possibly reduced by the input costs of converter.

Together with this the implementation of larger amount of equipment to existing conception can be realized. More than ten years ago, a typical value for power density of proposed converters was around $0,304 \mathrm{~W} / \mathrm{cm} 3$ (5W/inch3). Nowadays its value for the same device is targeting values around $1,5 \mathrm{~W} / \mathrm{cm} 3$ (25W/inch3). If this trend will continue, the concept of proposed converters will need to fulfill target values at the level of $1,8 \mathrm{~W} / \mathrm{cm} 3$ (30W/inch3).

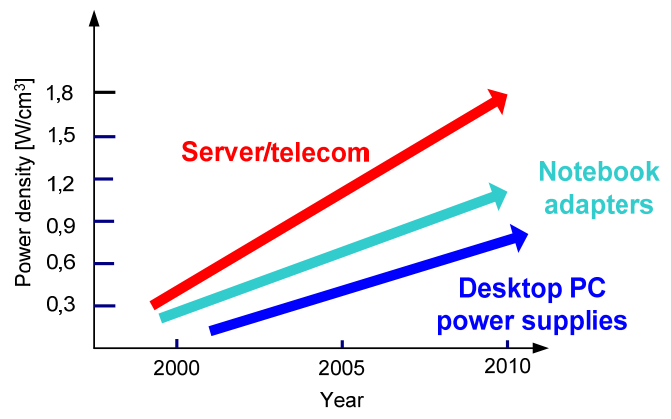

FIGURE II. TREND OF THE POWER DENSITY GROW.

There are several ways, how to meet upcoming requirements [4] - [6]. If we summarize existing trends, then it is possible to point out main factors, which influence qualitative indexes of converters:

- selection of proper semiconductor devices

- selection of proper material and geometry of transformer

- investigation of gain characteristic of power converter

In this paper, the second approach i.e. derivation of the optimal selection and design procedure of high frequency transformer, for front-end converter will be described. Main emphasis will be given on the gain of the upcoming efficiency standard.

\section{High Frequency TRANSFORMER's MAGNETIC MATERIALS}

Main aim of each application of power electronic system is 
to develop cheap, reliable and small high frequency transformer. Continual increase of system's switching frequencies (due to requirement on power density increase), had stimulated investigation of design, structural composition and material properties of inductive components. However nowadays, a lot of sophisticated software used for electromagnetic analysis exists. They allow to understand the problems that are usually theoretically difficult for description, or are complicated and time lengthy when considering the use of experimental analysis.

Typical example can be "fem" investigation of the characteristics of a highly non-linear magnetic material. As related with arrival of $\mathrm{SiC}$ components, continual growth of the switching frequency is expected [7]. Consequently, the field of material engineering of magnetic components must be ready to answer and adapt on the upcoming trend. The ratio between performance parameters and achievable switching frequency is a major qualitative indicator of the progress of power semiconductor devices. Together with these indicators, the quality of magnetic materials must also be evaluated.

Low losses, high value of saturation induction, and possibility of high temperature operation are primary characteristics of the material that may be suited for the construction of high frequency transformer with high power density, and high efficiency. Due to above reasons, there is a need to categorize power sources into basic groups, which differ from the nominal performance point of view. The first category is defined as low power sources with output power of $(<1 \mathrm{~kW})$ and with very high switching frequency $(>1 \mathrm{MHz})$. The second category are power sources with high output power $(>10 \mathrm{~kW})$ and with medium value of switching frequency $(<100 \mathrm{kHz})$ and the last category is covered by the power sources with medium value of output power $(1-10 \mathrm{~kW})$ and with the high value of switching frequency $(100 \mathrm{kHz}-200$ $\mathrm{kHz}$ ) [8]-[10].

\section{A. Proposed magnetic material selection}

According to the target application, which is front-end converter, it is necessary to define critical application properties, especially those, that are critical for transformer design - switching frequency and output power. Based on this, the factors, which influence selection procedure can be described with the use of Fig.III.

Based on the analysis of existing solutions it is possible to summarize the properties of the transformer power source for very high switching frequency $(100 \mathrm{KHz}-1 \mathrm{MHz})$ with low output power $(<1 \mathrm{~kW})$ as follows:

- Operating characteristics must correspond to the resonant function of converter

- Winding will be composed of high frequency wire

- Losses in winding and in the core must be very low

The most important challenge, regarding previous description (Fig.III), is given by the last three issues. In principle, it is very difficult to have magnetic material, that will have all parameters unequaled compared to others [11] - [13]. Therefore, it is necessary to proceed to a compromise. Next, three different materials, that may fit for utilization in target application (front - end converter, switching frequency up to 1 $\mathrm{MHz}$, output power $1 \mathrm{~kW}$ ), are compared:

- ferrite NiZn - 3F3

- amorphous material Metglas 2605SA

- $\quad$ supermally 2705

The main magnetic properties, which are necessary to be mutually compared are:

- operational frequency range

- operational temperature range

- initial permeability

- value of saturation induction

- Currie temperature

- specific losses in dependency on saturation induction and switching frequency

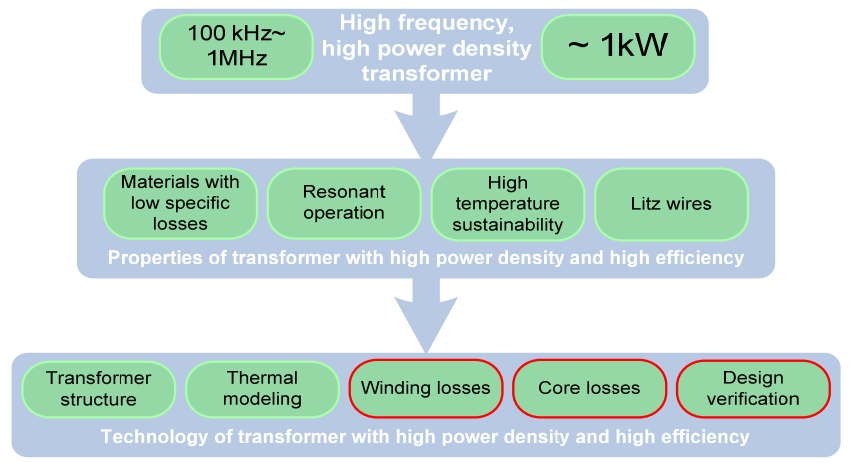

FIGURE III. FACTORS INFLUENCING SELECTION PROCEDURE OF TRANSFORMER CORE MATERIAL

TABLE I. MAGNETIC PROPERTIES OF COMPARED MATERIALS

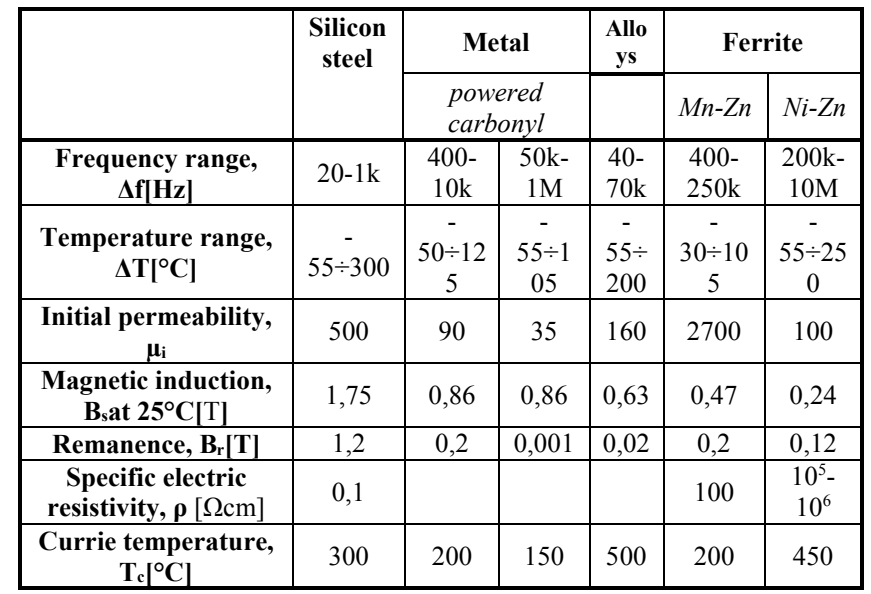

From table I. and fig. IV is clear, that amorphous metal Metglas 2605SA and Supermalloy 2705 have several times higher specific volume losses above frequency $200 \mathrm{kHz}$, compared to ferrite material. On the other side, their relative advantage is high value of saturation induction as well as high initial permeability [14]. This enables achievement of high value of inductance, almost at low number of turns. The negative effect of that, is increase of losses by eddy currents 
and higher hysteresis losses of magnetic core. Operational temperature during steady state of activity is highest for the ferrite 3F3 material, what predetermine it for wide spectrum of industrial applications.

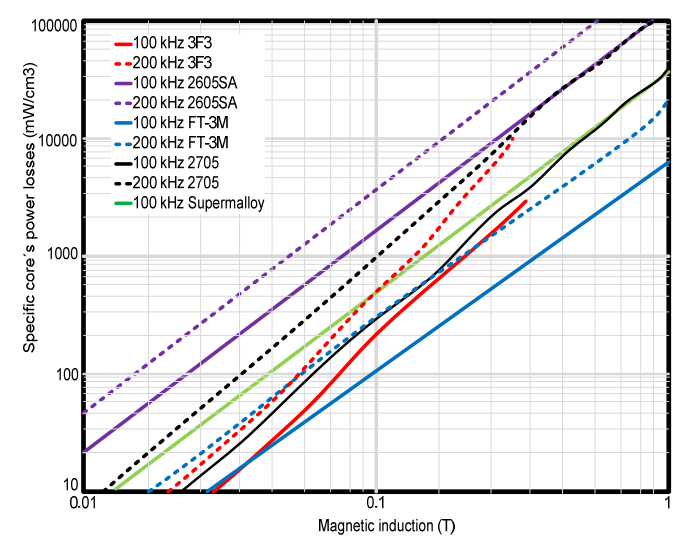

FIGURE IV. SPECIFIC VOLUME LOSSES OF COMPARED MATERIALS IN DEPENDENCY ON FREQUENCY AND SATURATION INDUCTION.

Previous comparisons show, that in order to lower transformer losses (hysteresis losses, winding losses, eddy current losses) during high frequency operation, the most valuable material is ferrite $\mathrm{Ni}-\mathrm{Zn} 3 \mathrm{~F} 3$.

\section{Design Procedure OF High Frequency TRANSFOERMER FOR FRONT-END CONVERTER}

From the fig. V. it can be seen, that effective design is determined by the mutual relationship of the input variables, critical operating parameters and of the design specifications.

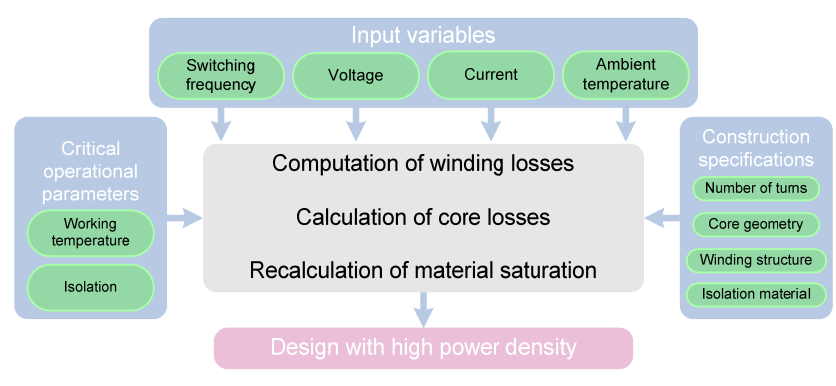

FIGURE V. DESIGN PROCEDURES AIMED FOR THE MINIMIZATION OF THE TRANSFORMER SIZE

From the point of optimization of transformer design, the reduction of overall losses is necessary. These losses are composed from losses in windings and losses in transformer core (hysteresis losses, eddy currents). As the following analysis shows, both components of transformer losses are affected by maximal value of magnetic induction, so the proper choice of this parameter is critical [15]. Based on [23] formula for the value of hysteresis losses is:

$$
P_{C u}=I_{t o t}^{2} R_{C u}=\frac{I_{t o t}^{2} n_{1}^{2}(M L T) \rho}{S_{O} K_{U}}
$$

$$
I_{t o t}=\sum_{j=1}^{k} \frac{n_{j}}{n_{1}} I_{j}
$$

where $\mathrm{I}^{2}$ tot - averaged RMS value of winding currents [A]

$\mathrm{R}_{\mathrm{Cu}}-$ resistance of conductor in winding [ $[\mathrm{]}$

$\rho-$ specific resistance of conductor $[\mu \Omega / \mathrm{cm}]$

$1_{j}$-length of the conductor [mm]

$\mathrm{n}_{1}$-number of turns - primary winding

(MLT) - mean length of turn [mm]

$\mathrm{S}_{\mathrm{O}}$-surface utilization factor $\left[\mathrm{mm}^{2}\right]$

The formulation of winding losses depending on value of saturation will be based on Farraday law of electromagnetic induction, wherein for $\mathrm{AC}$ part of magnetic induction next formula is valid:

$$
\Delta B=10^{4} \frac{\int_{t 1}^{t 2} u_{1}(t) d t}{2 n_{1} S_{j}}=10^{4} \frac{U_{1}}{2 n_{1} S_{j}}
$$

, where $u_{1}(t)$-value of voltage on given winding [V/ $\mu \mathrm{s}$ ]

$\mathrm{S}_{\mathrm{j}}$-area of core $\left[\mathrm{cm}^{2}\right]$

From equation (3) the number of turns for requested value of magnetic induction has this formulation:

$$
n_{1}=10^{4} \frac{U_{1}}{2 \Delta B S_{j}}
$$

Substituting (4) and (2) into (1) yields to required dependency of losses in transformer windings on induction ripple $\Delta \mathrm{B}$ :

$$
P_{C u}=10^{8}\left(\frac{\rho U_{1}^{2} I_{t o t}^{2}}{4 K_{U}}\right)\left(\frac{(M L T)}{S_{O} S_{j}^{2}}\right)\left(\frac{1}{\Delta B}\right)^{2}
$$

From above mentioned equations is clear, that for increasing of ripple content in magnetic induction, the losses in transformer windings will decrease rapidly. For second part of overall losses - losses in transformer core, is the situation opposite, since for increasing of maximum value of magnetic induction, the value also increase (6).

$$
P_{f e}=K_{f e} \Delta B^{\beta} S_{j} l_{m}
$$

, where $1_{\mathrm{m}}$-magnetic length of core field line[mm]

$\beta$ - constant (for ferrite 2,6 - 2,7)

$\mathrm{K}_{\mathrm{fe}}-$ parameter representing specific volume losses of material depending on saturation and switching frequency $\left[\mathrm{W} / \mathrm{cm}^{3}\right]$

Losses in transformer's core, in addition to value of saturation, depend on core geometry, which is defined by factor of area and length, and on material properties of magnetic (parameter $\mathrm{K}_{\mathrm{fe}}$ ). 
We can conclude, that the ideal design of transformer depends on optimal value of parameter $\Delta \mathrm{B}$ so the next formulation must be valid: $\mathrm{P}_{\mathrm{tot}}=\mathrm{P}_{\mathrm{Cu}}+\mathrm{P}_{\mathrm{fe}}=$ minimum. Graphical interpretation of this requirement is on fig.VI. To minimize the transformer losses, next formulation for optimal value of induction ripple must be valid:

$$
\frac{d P_{t o t}}{d(\Delta B)}=\frac{d P_{f e}}{d(\Delta B)}+\frac{d P_{C u}}{d(\Delta B)}=0
$$

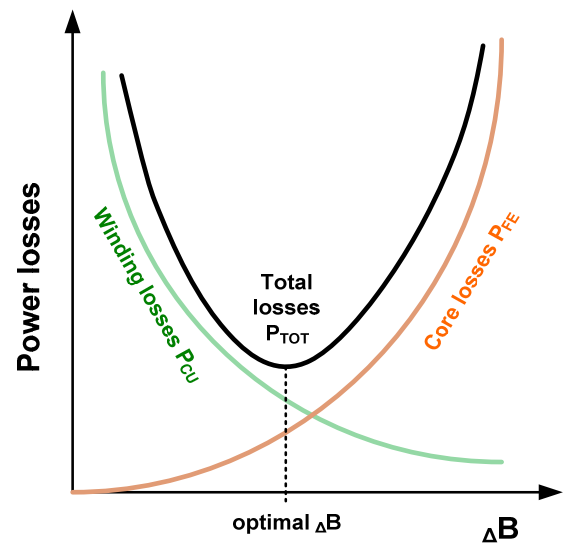

FIGURE VI. DEPENDENCY OF TRANSFORMER LOSSES ON THE RIPPLE OF MAGNETIC INDUCTION

It should be noted, that due to non-linear relationship between $P C u, P f e=f(\Delta B)$, the optimal value is not present for condition $\mathrm{Pfe}=\mathrm{PCu}$, but for:

$$
\frac{d P_{f e}}{d(\Delta B)}=-\frac{d P_{C u}}{d(\Delta B)}
$$
forms:

Derivations of individual parts of losses have the following

$$
\begin{gathered}
\frac{d P_{f e}}{d(\Delta B)}=\beta K_{f e}(\Delta B)^{(\beta-1)} S_{j} l_{m} \\
\frac{d P_{C u}}{d(\Delta B)}=-2\left(\frac{\rho U_{1}^{2} I_{t o t}^{2}}{4 K_{u}}\right)\left(\frac{(M L T)}{S_{O} S_{j}^{2}}\right)(\Delta B)^{-3}
\end{gathered}
$$

Substituting (9) and (10) into equation (8) and deriving parameter $\Delta \mathrm{B}$, the formulation for calculating of optimal value of induction ripple for given core geometry can be obtained:

$$
\Delta B=\left[10^{8} \frac{\rho U_{1}^{2} I_{t o t}^{2}}{2 K_{U}} \frac{(M L T)}{S_{O} S_{j}^{3} l_{m}} \frac{1}{\beta K_{f e}}\right]^{\left(\frac{1}{\beta+2}\right)}
$$

At this point, it should be noted, that equation (11) is valid only after choosing of particular transformer's core geometry (size and type). For this purpose, the dependence for determination of necessary dimensions of magnetics must be derived, according to previous analysis (5) - (11). The formula for overall losses $\mathrm{P}_{\text {tot }}=\mathrm{P}_{\mathrm{Cu}}+\mathrm{P}_{\mathrm{fe}}$, by use of equation (11) will be in form:

$$
P_{t o t}=\left[S_{j} l_{m} K_{f e}\right]\left(\frac{2}{\beta+2}\right)\left[\frac{\rho U_{1}^{2} I_{\text {tot }}^{2}}{4 K_{U}} \frac{(M L T)}{S_{O} S_{j}^{2}}\right]^{\left(\frac{\beta}{\beta+2}\right)}\left[\left(\frac{\beta}{2}\right)^{\left(\frac{\beta}{\beta+2}\right)}+\left(\frac{\beta}{2}\right)^{\left(\frac{2}{\beta+2}\right)}\right]
$$

After necessary modifications, equation (12) can be written into (13):

$$
\frac{S_{O}\left(S_{j}\right)^{(2(\beta-1) / \beta)}}{(M L T) l_{m}^{(2 / \beta)}}\left[\left(\frac{\beta}{2}\right)^{-\left(\frac{\beta}{\beta+2}\right)}+\left(\frac{\beta}{2}\right)^{\left(\frac{2}{\beta+2}\right)}\right]^{\left(\frac{\beta}{\beta+2}\right)}=\frac{\rho U_{1}^{2} I_{t o t}^{2} K_{f e}^{(2 / \beta)}}{4 K_{U}\left(P_{t o t}\right)^{((\beta+2) / \beta)}}
$$

,where left side of equation represents expression dependent only on geometry and dimensions of magnetics and right side represents expression, which is determined by specific parameters of final application. On the basis of (13), the dependency which expresses minimal value of geometrical constant can be derived. Value of this constant is determined by geometrical dimensions of magnetics $-\mathrm{K}_{\mathrm{gfe}}$ :

$$
K_{g f e}=\frac{S_{O}\left(S_{j}\right)^{(2(\beta-1) / \beta)}}{(M L T) l_{m}^{(2 / \beta)}}\left[\left(\frac{\beta}{2}\right)^{-\left(\frac{\beta}{\beta+2}\right)}+\left(\frac{\beta}{2}\right)^{\left(\frac{2}{\beta+2}\right)}\right]^{-\left(\frac{\beta}{\beta+2}\right)}
$$

For particular parameters of specific application, next formula must be valid:

$$
K_{g f e} \geq \frac{\rho U_{1}^{2} I_{t o t}^{2} K_{f e}^{(2 / \beta)}}{4 K_{U}\left(P_{t o t}\right)^{((\beta+2) / \beta)}} \cdot 10^{8}
$$

The optimal design procedure of high frequency transformer may be summarized as follows:

- first, based on given parameters of target application $\left(\mathrm{U}_{1}\right.$, $\mathrm{I}_{\text {tot }}, \mathrm{K}_{\mathrm{fe}}, \mathrm{K}_{\mathrm{U}}, \mathrm{P}_{\text {tot }}, \mathrm{f}_{\mathrm{SW}}$ ) select the geometrical constant.

- with the use of equation (11) recalculate the ripple content of magnetic induction. If the value of $\Delta \mathrm{B}$ is higher than $\mathrm{B}_{\text {sat }}$, then material with higher specific volume losses must be selected.

- calculation of primary and secondary turns.

- with the use of the number of turns, recalculate the $\Delta \mathrm{B}$ and consequently core and winding losses of transformer.

- If core and winding losses are higher then allowed, then selection of core with higher volume is a must. 


\section{Application Of Optimal Transformer Design Procedure On Proposed LlC CONVERTER}

Previous methodology of the optimal design of high frequency transformer was applied during design of proposed LLC converter. Its main electrical parameters are:

- switching frequency $=500 \mathrm{kHz}$, Output power $=500 \mathrm{~W}$

- Input voltage $=400 \mathrm{~V}$, Output voltage $=48 \mathrm{~V}$

- $\mathrm{K}_{\mathrm{fe}}=5 \mathrm{~W} / \mathrm{cm}^{3} ; \mathrm{K}_{\mathrm{U}}=0,5 ; \beta=2,6 ; \eta_{\text {transf }}=99,8 \%$

- $\mathrm{P}_{\mathrm{tot}}=0,9 \mathrm{~W}$

a) Computation of $U_{1}$ and $I_{\text {tot }}$

$U_{1}=D \cdot T_{S W} \cdot U_{I N M A X}=0,5 \cdot 2 e-6.400=400 \mathrm{~V} / \mu \mathrm{s}$

$I_{\text {tot }}=I_{1}+\frac{1}{n} I_{2}=\frac{10}{4}+\frac{1}{4} 10=5 \mathrm{~A}$

b) Computation of $K_{g f e}$

$K_{g f e} \geq \frac{1,724 e-6 \cdot(400 e-6)^{2} \cdot 25 \cdot 5^{(2 / 2,6)}}{4 \cdot 0,5 \cdot(0,9)^{(4,6 / 2,6)}} \cdot 10^{8}=1,5 e-3$

,whereby based on the catalog data of ferrite cores, PQ $20 / 16$ with $\mathrm{K}_{\mathrm{gfe}}=3,7 \mathrm{e}-3$ may be a proper choice.

TABLE II. MAGNETIC PROPERTIES OF COMPARED MATERIALS

\begin{tabular}{|c|c|c|c|c|c|c|}
\hline Core type & PQ20/16 & \multicolumn{1}{|c|}{} \\
\cline { 1 - 2 } $\begin{array}{c}\text { Geometric } \\
\text { constant }\end{array}$ & $\begin{array}{c}\text { Geometric } \\
\text { constant }\end{array}$ & $\begin{array}{c}\text { Cross- } \\
\text { sectional } \\
\text { area }\end{array}$ & $\begin{array}{c}\text { Bobbin } \\
\text { winding } \\
\text { area }\end{array}$ & $\begin{array}{c}\text { Mean } \\
\text { lenght per } \\
\text { turn }\end{array}$ & $\begin{array}{c}\text { Magnetic } \\
\text { path } \\
\text { lenght }\end{array}$ & $\begin{array}{c}\text { Weight } \\
\text { core }\end{array}$ \\
\hline $\mathrm{Kg}\left[\mathrm{cm}^{5}\right]$ & $\mathrm{Kgfe}\left[\mathrm{cm}^{\mathrm{x}}\right]$ & $\mathrm{Sj}\left[\mathrm{cm}^{2}\right]$ & $\mathrm{So}\left[\mathrm{cm}^{2}\right]$ & $\mathrm{MLT}[\mathrm{cm}]$ & $\operatorname{lm}[\mathrm{cm}]$ & {$[\mathrm{g}]$} \\
\hline $2,24 \mathrm{e}-3$ & $3,7 \mathrm{e}-3$ & 0,62 & 0,256 & 4,4 & 3,74 & 13 \\
\hline
\end{tabular}

c) Computation of $\Delta B$

$\Delta B==\left[10^{8} \frac{1,724 e-6 \cdot(400 e-6)^{2} \cdot 25}{2.0,5} \cdot \frac{4,4}{0,256 \cdot(0,62)^{3} \cdot 3,74} \cdot \frac{1}{2,6.5}\right]^{(1 / 4,6)}=230 \mathrm{mT}$

What pose as high value compared to allowed saturation of core material $3 \mathrm{~F} 3$ fyFerroxcube $\left(\mathrm{B}_{\max (500 \mathrm{kHz})}=150 \mathrm{mT}\right)$. Therefore selection of core with higher volume and higher specific volume losses is necessary. Selected core is the PQ26/20 with $K_{\text {gfe }}=9,4 e-3$.

TABLE III. MAGNETIC PROPERTIES OF COMPARED MATERIALS

\begin{tabular}{|c|c|c|c|c|c|c|}
\hline Core type & PQ26/25 & & & & & \\
\hline $\begin{array}{c}\text { Geometric } \\
\text { constant }\end{array}$ & $\begin{array}{c}\text { Geometric } \\
\text { constant }\end{array}$ & $\begin{array}{c}\text { Cross- } \\
\text { sectional } \\
\text { area } \\
\end{array}$ & $\begin{array}{c}\text { Bobbin } \\
\text { winding } \\
\text { area }\end{array}$ & $\begin{array}{c}\text { Mean } \\
\text { lenght per } \\
\text { turn }\end{array}$ & $\begin{array}{c}\text { Magnetic } \\
\text { path } \\
\text { lenght }\end{array}$ & $\begin{array}{l}\text { Weight } \\
\text { core }\end{array}$ \\
\hline $\mathrm{Kg}\left[\mathrm{cm}^{5}\right]$ & $\operatorname{Kgfe}\left[\mathrm{cm}^{\mathrm{x}}\right]$ & $\mathrm{Sj}\left[\mathrm{cm}^{2}\right]$ & So $\left[\mathrm{cm}^{2}\right]$ & $\operatorname{MLT}[\mathrm{cm}]$ & $\operatorname{lm}[\mathrm{cm}]$ & [g] \\
\hline 0.0839 & $7.2 \mathrm{e}-3$ & 1.19 & 0.333 & 5,62 & 4.63 & 31 \\
\hline
\end{tabular}

d) Recalculation of $\Delta B$

$$
\Delta B=\left[10^{8} \frac{1,724 e-6 \cdot(400 e-6)^{2} \cdot 25}{2.0,5} \cdot \frac{5,62}{0,503 \cdot(1,18)^{3} \cdot 5,55} \cdot \frac{1}{2,6.5}\right]^{(1 / 4,6)}=124 \mathrm{mT}
$$

what is acceptable result, and further computations can be provided. e) Computation of primary and secondary turns

$$
\begin{aligned}
& n_{1}=10^{4} \frac{U_{1}}{2 \triangle B S_{j}}=10^{4} \frac{400 e-6}{2.124 e-3.1,18}=14 \\
& n_{2}=\frac{n_{1}}{n}=3,5
\end{aligned}
$$

f) Recalculation of $\triangle B$, computation of $P_{c u}, P_{f e}$ and $P_{t o t}$

$$
\begin{gathered}
\Delta B=10^{4} \frac{U_{1}}{2 n_{1} S_{j}}=10^{4} \frac{400 e-6}{2 .(16.1,18)}=106 \mathrm{mT} \\
P_{f e}=K_{f e} \Delta B^{\beta} S_{j} l_{m}=5 .(106 e-3)^{2,6} \cdot 1,18.5,55=0,096 \mathrm{~W} \\
P_{C u}=10^{8}\left(\frac{\rho U_{1}^{2} I_{\text {tot }}^{2}}{4 K_{U}}\right)\left(\frac{(M L T)}{S_{O} S_{j}^{2}}\right)\left(\frac{1}{\Delta B}\right)^{2}= \\
=10^{8} \frac{1,724 e-6 .(400 e-6)^{2} \cdot 5^{2}}{4.0,5} \cdot \frac{5,62}{1,18.0,503^{2}} \cdot \frac{1}{(106 e-3)^{2}}= \\
=3,448 e-4.18,82.88,9=0,57 \mathrm{~W} \\
P_{t o t}=P_{f e}+P_{C u}=0,666 \mathrm{~W}
\end{gathered}
$$

The final recalculation confirmed, that selected core PQ26/20 may be sufficiently designed for the use in proposed converter. The other suitable core geometries, whose influence on the efficiency will be investigated are EE30 and POT core 2616.

\section{INVESTIGATION OF THE INFLUENCE OF TRANSFORMER CORE GEOMETRY ON THE EFFICIENCY OF PROPOSED CONVERTER}

This chapter shows simulation results of efficiency investigation of proposed converter, whereby parameter that has been changed was the geometry of the transformer core.

\begin{tabular}{|c|c|c|c|c|c|c|c|}
\hline $\begin{array}{l}\text { Core } \\
\text { type }\end{array}$ & $\begin{array}{c}\text { Geom } \\
\text { etric } \\
\text { Const } \\
\text { ant } \\
\end{array}$ & $\begin{array}{l}\text { Geom } \\
\text { etric } \\
\text { Const } \\
\text { ant } \\
\end{array}$ & $\begin{array}{c}\text { Cross- } \\
\text { sectional } \\
\text { area }\end{array}$ & $\begin{array}{c}\text { Bobbin } \\
\text { winding } \\
\text { area }\end{array}$ & $\begin{array}{c}\text { Mean } \\
\text { lenght } \\
\text { per } \\
\text { turn } \\
\end{array}$ & $\begin{array}{c}\text { Magneti } \\
\text { c path } \\
\text { lenght }\end{array}$ & $\begin{array}{c}\text { Core } \\
\text { weigh } \\
t\end{array}$ \\
\hline & $\begin{array}{c}\mathrm{K}_{\mathrm{g}} \\
{\left[\mathrm{cm}^{5}\right]}\end{array}$ & $\begin{array}{c}\mathrm{K}_{\mathrm{gfe}} \\
{\left[\mathrm{cm}^{\mathrm{x}}\right]}\end{array}$ & $\begin{array}{c}\mathrm{S}_{\mathrm{j}} \\
{\left[\mathrm{cm}^{2}\right]}\end{array}$ & $\begin{array}{c}\mathrm{S}_{\mathrm{O}} \\
{\left[\mathrm{cm}^{2}\right]}\end{array}$ & $\begin{array}{l}\text { MLT } \\
{[\mathrm{cm}]}\end{array}$ & $\begin{array}{c}\mathrm{l}_{\mathrm{m}} \\
{[\mathrm{cm}]}\end{array}$ & {$[\mathrm{g}]$} \\
\hline $\begin{array}{c}\text { PQ26 } \\
/ 20\end{array}$ & $\begin{array}{c}0.083 \\
9\end{array}$ & $\begin{array}{c}7.2 \mathrm{e}- \\
3\end{array}$ & 1.19 & 0.333 & 5,62 & 4.63 & 31 \\
\hline EE30 & $\begin{array}{c}0.085 \\
7 \\
\end{array}$ & $\begin{array}{c}6.7 \mathrm{e}- \\
3 \\
\end{array}$ & 1,09 & 0.476 & 6.6 & 5.77 & 32.4 \\
\hline $\begin{array}{c}\text { POT2 } \\
616\end{array}$ & $\begin{array}{c}0.069 \\
1\end{array}$ & $\begin{array}{c}8.2 \mathrm{e}- \\
3\end{array}$ & 0.948 & 0,406 & 5.28 & 3.75 & 20 \\
\hline
\end{tabular}
Calculation of each transformer (PQ26/25, EE30, and POT core 2616) was done with the use of optimal procedure, which is described in previous chapter. Next table (table IV) shows main parameters, that are influencing main electrical variables of proposed transformer (saturating induction, number of turns, core losses and copper losses), see table V.

TABLE IV. MAIN ELECTRICAL PARAMETERS OF CORE GEOMETRIES 
TABLE V. ELECTRICAL VARIABILES OF PROPOSED TRANSFORMER, WHICH ARE INFLUENCING EFFICIENCY OF CONVERTER

\begin{tabular}{|c|c|c|c|c|c|c|}
\hline $\begin{array}{l}\text { Core } \\
\text { type }\end{array}$ & $\begin{array}{c}\text { Saturation } \\
\text { magnetic } \\
\text { induction }\end{array}$ & $\begin{array}{c}\text { Number of } \\
\text { primary } \\
\text { turns }\end{array}$ & $\begin{array}{c}\text { Number of } \\
\text { secondary } \\
\text { turns }\end{array}$ & $\begin{array}{c}\text { Cop } \\
\text { per } \\
\text { losse } \\
\text { s } \\
\end{array}$ & $\begin{array}{l}\text { Core } \\
\text { losses }\end{array}$ & $\begin{array}{c}\text { Total power } \\
\text { losses } \\
\text { of } \\
\text { transformer }\end{array}$ \\
\hline \multirow[b]{2}{*}{$\begin{array}{c}\text { PQ26 } \\
/ 20 \\
\end{array}$} & $\begin{array}{c}\Delta \mathrm{B} \\
{[\mathrm{mT}]}\end{array}$ & $\begin{array}{c}\mathrm{N}_{1} \\
\text { [turns] }\end{array}$ & $\begin{array}{c}\mathrm{N}_{21}, \mathrm{~N}_{22} \\
\text { [turns] }\end{array}$ & $\begin{array}{l}\mathrm{P}_{\mathrm{CU}} \\
{[\mathrm{W}]}\end{array}$ & $\begin{array}{l}P_{F E} \\
{[W]}\end{array}$ & $\begin{array}{l}\text { Ртот }_{\text {то }} \\
{[\mathrm{W}]}\end{array}$ \\
\hline & 139 & 12 & 3 & 0,21 & 0,16 & 0,37 \\
\hline EE30 & 135 & 13 & 3,5 & 0,22 & 0,171 & 0,391 \\
\hline \begin{tabular}{|l} 
POT \\
2616
\end{tabular} & 162 & 13 & 3 & 0,19 & 0,1506 & 0,346 \\
\hline
\end{tabular}

Fig. VII shows, that shape and geometry of high frequency transformer highly influence efficiency of proposed converter in whole regulation range. Best efficiency was achieved for PQ26/20 core. It is clear to say, that coming standard can be achieved, when proper core is selected. The PQ cores have been developed in particular for transformers in switch-mode power supplies. The insertion height of these cores can be adjusted while retaining the same footprint by appropriate adaptation of the cores. Compared with conventional $\mathrm{ETD} / \mathrm{ER} / \mathrm{E}$ core designs, the main advantage of the PQ cores is the stable round center leg and the larger outer surfaces. As a result of the round center leg and the larger surface area for the windings, the length of the copper wire can be reduced. As a consequence, costs can be lowered in the transformer production. Moreover, the larger outer areas provide better heat dissipation. The PQ core shape has been optimized in such a way that the same transformer performance as for an E core can be reached with smaller dimensions and less weight [16] [18].

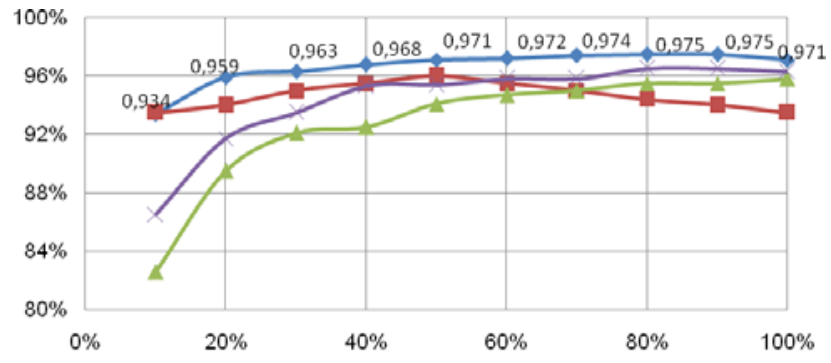

$\rightarrow$ PQ26/20 core - - comming standard - EE30/15/7 core $\longrightarrow$ POT core 2616

FIGURE VII. DEPENDENCY OF EFFICNIENCY ON OUTPUT POWER FOR DIFFERENT CORE GEOMETRIES OF TRANSFORMER.

Last figure shows (Fig.VIII), that the geometry of transformer core even influences waveforms of the electrical parameters in the circuit. The waveforms have been received during nominal operation at full load conditions. What must be noticed, is that the highest voltage distortion occurs just in the case of the core with the highest efficiency in whole power range (PQ core). That means, that not only efficiency is the only main quality indicator of power supplies that must be improved, but also electro-magnetic interference acts as very important part of the optimization. Therefore, the future work will be focused also on the investigation of other phenomenon's that influences quality indicators of power supplies.

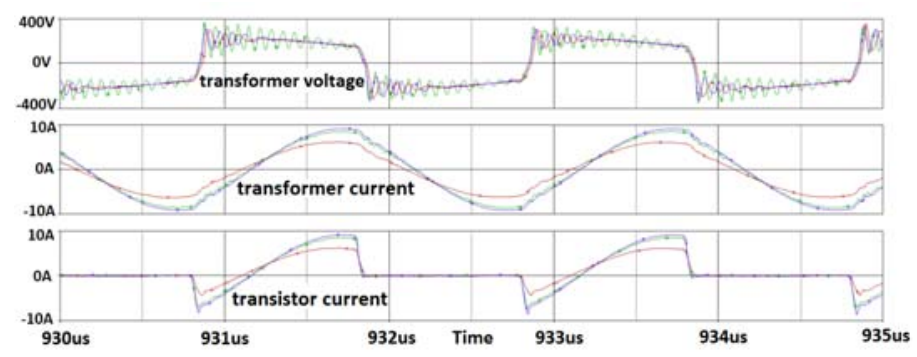

FIGURE VIII. WAVEFORMS OF THE ELECTRICAL VARIABLES OF PROPOSED LLC CONVERTER WITH DIFFERENT GEOMETRY OF TRANSFORMER (GREEN - PQ CORE, BLUE - POT CORE, RED - E CORE).

\section{CONCLUSION}

Paper first deals with the description of the optimal design procedure of high frequency converter. At the end of the paper, the simulation experiment has been provided, in order to investigate, how much shape and geometry of transformer can influence the efficiency of converter. The results show, that proper selection of core geometry, has high impact on the achievement of the efficiency values of coming standard. Future work will further focus on the design of universal methodology for semiconductor devices selection, by which it will be possible to lift up efficiency of power converters that are operating at very high switching frequencies. Furthermore, the backward investigation of the influence of proposed methodologies on other qualitative indexes (EMI, power density) will be performed

\section{ACKNOWLEDGMENT}

This research was funded by a grant (No. 1/0579/14) from the Slovak Grant National agency VEGA.

\section{REFERENCE}

[1] JOVANOVIC, M. M.:Technology Drivers and Trends in Power Supplies for Computer/telecom, APEC 2006, Plenary session presentation.

[2] HEATH, C.C.: The Market for Distributed Power Systems, Proc. of IEEE APEC '91, 1991, March 1991, pp. 225-229.

[3] TABISZ, W.A., JOVANOVIC, M.M., LEE, F.C.: Present and Future of Distributed Power Systems, Proc. of IEEE APEC '92, 1992, pp. 11-18.

[4] LEE, F.C., BARBOSA, P., XU, P., ZHANG, J., YANG, B. CANALES, F.:Topologies and Design Considerations for Distributed Power System Applications, Proc. of the IEEE, vol. 89, No. 6, June 2001, pp. 939-950.

[5] YANG, B.: Topology Investigation for Front End DC-DC Power Conversion for Distributed Power System, Ph.D dissertation, 2003.

[6] FRIVALDSKY, M., DRGONA, P., SPANIK, P.: Experimental Analysis and Optimization of Key Parameters of ZVS Mode and its Application in the Proposed LLC Converter Designed for Distributed Power System Application, Electrical Power and Energy Systems, vol. 47, pp.448-456, ISSN 0142-0615.

[7] FRIVALDSKY, M., DRGONA, P., SPANIK, P.: Hard Switching Process Optimization for Selected Transistor Suited for High Power and High Frequency Operation, J. of Energy and Power Engineering,vol. 4, No. 12, ISSN 1934-8975. 
[8] SPANIK, P., FRIVALDSKY, M., DRGONA, P., KANDRAC, J.: Efficiency Increase of Switched Mode Power Supply trough Optimization of Transistor's Commutation Mode, Electronics and Electrical Engineering = Elektronika ir elektrotechnika,vol. 9(105), 2010, pp. 49-52, ISSN 1392-1215.

[9] GRMAN, L., HRASKO, M., KUCHTA, J.: Single Phase PWM Rectifier in Traction Application, J. of Electrical Engineering-elektrotechnicky casopis, vol. 62, No. 4, pp. 206 - 212, August 2011.

[10] FERKOVA, Z., FRANKA, M., KUCHTA, J.: Electromagnetic Design of Ironless Permanent Magnet Synchronous Linear Motor, Intern. symposium on power electronics, electrical drives, automation and motion (SPEEDAM), Italy, June 2008, pp. 721-726.

[11] KOVACOVA, I., KOVAC, D.: Inductive Coupling of Power converter's EMC, Acta Polytechnica Hungarica, vol. 6, No. 2, pp. 41-53, 2009.

[12] Dobrucky, B., Laskody, T., Prazenica, M., Kascak, S.: Analysis of VSI and MxC Converters Fed Two-Phase Induction Motor with the Same Magnitude of Fundamental Harmonic Voltages, In: International Review of Electrical Engineering - IREE, Vol. 9, No. 5 2014, pp. 989-902, ISSN

[13] Dobrucky, B., Laskody, T., Prazenica, M.: A Novel Supply System for Two- Phase Induction Motor by Single Leg Matrix Converter, In: Elektronika ir Elektrotechnika, Vol. 21, No. 4, 2015, pp. 13-16, ISSN

[14] 1392-1215BRANDSTETTER, P., CHLEBIS, P., PALACKY, P.: Application of RBF Network in Rotor Time Constant Adaptation, Elektronika IR elektrotechnika, No. 7, pp.21-26, 2011.

[15] LONCOVA, Z., HARGAS, L., KONIAR, D., HRIANKA, M., SIMONOVA, A.: Parameters measurement of the object in a video sequence, In: 13th International IFAC Conference on Programmable Devices and Embedded Sysytems : Cracow, Poland, 13-15 May 2015, -

[16] ISSN 2405-8963OCILKA, M., KOVAC, D., KOVACOVA, I., PERDULAK, J., GLADY, A., MAMCHUR, D., ZACHEPA, I., VINCE, T., MOLNAR, J.: Serial Resonant Converter and Load Coil for High Frequency Heating, Communications - Scientific Letters of University of Zilina, vol. 15, No.3, 2013, ISSN 1335-4205.

[17] SZYCHTA, E., KRAWCZYK, G., BUDAY, J., KUCHTA, J., MICHALIK, J.: Simulation Studies of the Underground DC TractionSubstation with and without Energy Storage Device, Communications - Scientific Letters of University of Zilina, vol. 15, No.3, 2013, ISSN 1335-4205.

[18] HIMMELSTOSS, F.A., VOTZI, H.L.: CombinedForwardflybackConverter with only Two Diodes, Function and Modelling, Communications - Scientific Letters of University of Zilina, No.2a, 2011, ISSN 1335-4205.

[19] SPANIK, P., KANDRAC, J., FRIVALDSKY, M., DRGONA, P.: Verification of Operation Modes of Designed LLC Resonant Converter, Communications - Scientific Letters of University of Zilina, No.2a, 2011, ISSN 1335-4205. 